\title{
Glosa do uchwały SN z 5 II 2010 r., III CZP 127/09*
}

Zagadnienie prawne przedstawione Sądowi Najwyższemu do rozstrzygnięcia powstało na tle następującego stanu faktycznego. Wspólnota mieszkaniowa wyraziła zgodę na obciążenie gruntu wchodzącego w skład nieruchomości wspólnej służebnością drogową. W tym celu podjęto uchwałę wyrażającą zgodę oraz udzielającą zarządowi pełnomocnictwa do złożenia oświadczenia o jej ustanowieniu. Wniosek o wpis służebności w księdze wieczystej został jednak oddalony przez Sąd Rejonowy w S. Sąd Okręgowy w S., rozpoznając apelację na postanowienie Sądu Rejonowego, przedstawił Sądowi Najwyższemu następujące pytanie prawne: „Czy w trybie przewidzianym przez art. 21 ust. 3 ustawy z dnia 24 czerwca 1994 roku o własności lokali ${ }^{1}$ [...] wspólnota mieszkaniowa może udzielić zarządowi wspólnoty mieszkaniowej pełnomocnictwa do złożenia oświadczenia o ustanowieniu ograniczonego prawa rzeczowego (służebności gruntowej), w celu wykonania uchwały w sprawie nie wymienionej w art. 22 ust. 3 pkt 5, 5a i 6 tej ustawy, ze skutkiem w stosunku do właścicieli wszystkich lokali?”. W odpowiedzi na tak postawione pytanie Sąd Najwyższy orzekł, że „na podstawie art. 21 ust. 3 ustawy $z$ dnia 24 czerwca 1994 r., o własności lokali [...] wspólnota mieszkaniowa nie może

* Opubl. w OSP 10/2010, poz. 98, s. 692-696, z glosą krytyczną M. Gutowskiego.

1 Tekst jedn. Dz.U. z 2000 r. Nr 80, poz. 903, ze zm. 
udzielić zarządowi pełnomocnictwa do złożenia oświadczenia o ustanowieniu służebności drogowej”.

Przed przystąpieniem do analizy zagadnienia prawnego przedstawionego Sądowi Najwyższemu do rozstrzygnięcia należy ustalić, jakie rozumienie nadać stanowisku tego sądu wyrażonemu w odpowiedzi na pytanie Sądu Okręgowego w S. Zapoznanie się z tezą uchwały Sądu Najwyższego może sugerować, że istnieje rozbieżność w sformułowaniu użytym w pytaniu prawnym Sądu Okręgowego a odpowiedzią zawartą w uchwale Sądu Najwyższego. Pytanie dotyczyło bowiem tego, czy możliwe jest udzielenie pełnomocnictwa zarządowi wspólnoty mieszkaniowej w trybie art. 21 ust. 3 u.w.l., na podstawie którego zarząd będzie mógł składać oświadczenia ze skutkiem w stosunku do właścicieli wszystkich lokali, pomimo że przedmiotem uchwały, na podstawie której takie pełnomocnictwo jest udzielane, jest sprawa niewymieniona explicite $\mathrm{w}$ tym przepisie. Sąd Najwyższy odpowiedział, że na podstawie art. 21 ust. 3 u.w.l. wspólnota mieszkaniowa nie może udzielić zarządowi pełnomocnictwa do złożenia takiego oświadczenia.

W celu wyjaśnienia tej rozbieżności niezbędne wydaje się przytoczenie treści powoływanych przepisów. Zgodnie $z$ art. 21 ust. 3 u.w.l. „zarząd na podstawie pełnomocnictwa, o którym mowa w art. 22 ust. 2, składa oświadczenia w celu wykonania uchwał w sprawach, o których mowa w art. 22 ust. 3 pkt 5, 5a i 6, ze skutkiem w stosunku do właścicieli wszystkich lokali”. Artykuł 22 ust. 2, do którego ten przepis się odwołuje, stanowi, że „do podjęcia przez zarząd czynności przekraczającej zakres zwykłego zarządu potrzebna jest uchwała właścicieli lokali wyrażająca zgodę na dokonanie tej czynności oraz udzielająca zarządowi pełnomocnictwa do zawierania umów stanowiących czynności przekraczające zakres zwykłego zarządu w formie prawem przewidzianej”. Sentencję uchwały można by rozumieć w ten sposób, że pełnomocnictwo $z$ art. 22 ust. 2 u.w.l. może być udzielone tylko w sprawach explicite wymienionych $\mathrm{w}$ art. 21 ust. 3 u.w.l. (tj. zawartych w art. 22 ust. 3 pkt 5, 5a i 6) ${ }^{2}$. Takie

2 Takie rozumienie glosowanej uchwały zdaje się, że przyjął A. Turlej w: R. Strzelczyk, A. Turlej, Własność lokali. Komentarz, wyd. 2, Warszawa 2010, s. 435 i 442 . Jeżeli by je przyjąć, wówczas należałoby podzielić pogląd 
rozumienie omawianej uchwały jest jednak moim zdaniem niewłaściwe. Uchwała stanowi bowiem wyraźnie, że „na podstawie art. 21 ust. 3 [...] wspólnota mieszkaniowa nie może udzielić zarządowi pełnomocnictwa”. Artykuł 21 ust. 3 u.w.1. sam w sobie nie jest podstawą do udzielenia pełnomocnictwa. Taką podstawę stanowi art. 22 ust. 2 u.w.l., do którego ten przepis się odnosi. Sens art. 21 ust. 3 uwidacznia się w jego ostatnim fragmencie, który stanowi, iż oświadczenie złożone na podstawie pełnomocnictwa $z$ art. 22 ust. 2 u.w.1. i dotyczące wymienionych w nim uchwał odnosi skutek w stosunku do właścicieli wszystkich lokali. W konsekwencji sentencję uchwały należy moim zdaniem odczytywać w ten sposób, że oświadczenie zarządu wspólnoty mieszkaniowej złożone na podstawie pełnomocnictwa udzielonego zgodnie $z$ art. 22 ust. 2 u.w.l., lecz w celu wykonania innej uchwały niż wymieniona w art. 22 ust. 3 pkt 5, 5a i 6 nie odnosi skutku w stosunku do właścicieli wszystkich lokali na podstawie art. 21 ust. 3 u.w.l.

Przechodząc do meritum zagadnienia prawnego przedstawionego Sądowi Najwyższemu i odczytując treść uchwały w powyżej przedstawiony sposób, należy w pierwszej kolejności podkreślić, że wspólnota mieszkaniowa jest niepełną osobą prawną w rozumieniu art. $33^{1}$ k.c. ${ }^{3}$ powołaną do utrzymywania $\mathrm{w}$ należytym stanie nieruchomości wspólnej. Jednocześnie należy jasno odróżnić samą wspólnotę mieszkaniową, rozumianą jako podmiot prawa (oraz jej majątek), od konstrukcji współwłasności nieruchomości wspólnej. Udziały w nieruchomości wspólnej należą bowiem do majątku każdego $\mathrm{z}$ właścicieli lokali, który o nim decyduje ${ }^{4}$.

autora, że ustawodawca przewidział w art. 22 ust. 2 u.w.l. generalną kompetencję do udzielania pełnomocnictwa zarządowi w odniesieniu do czynności przekraczających zakres zwykłego zarządu, nie limitując ich jedynie do przypadków wymienionych w art. 21 ust. 3 u.w.1. Zestawiając ze sobą oba przepisy w kontekście takiej interpretacji glosowanej uchwały SN, należałoby uznać, że katalog wymieniony w art. 21 ust. 3 jest katalogiem niezamkniętym. Zob. także glosę do niniejszej uchwały SN M. Gutowskiego w OSP 10/2010, poz. 98, s. 693-696.

3 Zob. uchwałę SN (7) z 21.12.2007 r., III CZP 65/2007, OSNC 2008/7-8/69 (zasada prawna) do której się przychylam.

4 Zob. uzasadnienie uchwały SN (7) z 21.12.2007 r., III CZP 65/07, OSNC 2008/7-8/69. 
Zarząd nieruchomością wspólną może być we wspólnocie mieszkaniowej umowny (co jest preferowane) lub ustawowy (subsydiarny wobec zarządu umownego ${ }^{5}$ ). Przy zarządzie ustawowym sytuacja prawna zależy od tego, czy mamy do czynienia z tzw. małą czy dużą wspólnotą mieszkaniową ${ }^{6}$. Przy tzw. dużej wspólnocie mieszkaniowej istnieje przymus ustanowienia zarządu (art. 20 ust. 1 u.w.1.) ${ }^{7}$. Sposób jego działania zależy od tego, czy podejmuje on czynności zwykłego zarządu, czy czynności przekraczające zakres zwykłego zarządu. Czynności zwykłego zarządu podejmuje bowiem zarząd samodzielnie (art. 22 ust. 1 u.w.1.), natomiast podjęcie czynności przekraczających zakres zwykłego zarządu wymaga istnienia uchwały właścicieli lokali wyrażającej zgodę oraz udzielającej zarządowi pełnomocnictwa do zawierania umów stanowiących czynności przekraczające zakres zwykłego zarządu w formie prawem przewidzianej (art. 22 ust. 2 u.w.l.).

W zakresie czynności przekraczających zakres zwykłego zarządu można w mojej ocenie wyróżnić dwie grupy czynności, mianowicie takie, które dotyczą wyłącznie administrowania nieruchomością wspólną, oraz takie, które ingerują w prawo własności przysługujące właścicielom lokali, a dotyczące nieruchomości wspólnej

5 Jest on subsydiarny w tym sensie, że przepisy rozdziału 4 u.w.l. znajdują zastosowanie wówczas, gdy w umowie (lub uchwale zaprotokołowanej przez notariusza) nie określono sposobu zarządu (art. 18 ust. 3 u.w.1.). Znajdują one odpowiednie zastosowanie także wtedy, gdy na podstawie umowy powierzono zarząd osobie fizycznej lub prawnej i brak jest odmiennych postanowień umowy (art. 33 u.w.1.).

6 Tzn. taką, gdzie liczba lokali wyodrębnionych i niewyodrębnionych jest większa niż siedem (art. 20 u.w.1.).

7 Zgodnie $z$ art. 21 ust. 1 u.w.l. zarząd kieruje sprawami wspólnoty mieszkaniowej i reprezentuje ją na zewnątrz oraz w stosunkach między wspólnotą a poszczególnymi właścicielami lokali.

8 Przykładowe wymienienie czynności przekraczających zakres zwykłego zarządu zawiera art. 22 ust. 3 u.w.1. W odniesieniu do niego por. E. Bończak-Kucharczyk, Własność lokali i wspólnota mieszkaniowa. Komentarz, Warszawa 2010, s. 396-397 i przedstawione tam rozróżnienie na „czynności związane ze wspólnym gospodarowaniem nieruchomością, rozliczaniem kosztów i prowadzeniem spraw finansowych” oraz „czynności bezpośrednio związane z uprawnieniami właścicielskimi”. Pomimo zbieżności terminologicznej przedstawiona w niniejszej glosie kwalifikacja poszczególnych 
Do pierwszej grupy czynności, tj. takich, które dotyczą wyłącznie administrowania (gospodarowania) nieruchomością wspólną, można zaliczyć np. zawarcie umowy o kosztowne ocieplenie budynku. Moim zdaniem przykładem może być tu także nabycie nieruchomości, lecz - co należy podkreślić - jedynie w celu związanym $z$ administrowaniem nieruchomością wspólną (np. nabycie odrębnej własności lokalu przeznaczonego na siedzibę zarządu wspólnoty).

W odniesieniu do tych czynności wspólnota mieszkaniowa działa jako niepełna osoba prawna i w ramach przyznanej jej zdolności prawnej nabywa prawa i obowiązki związane $z$ administrowaniem nieruchomością wspólną do własnego majątku. Jak już wspomniano, podstawą do dokonania takich czynności przez zarząd jest podjęcie uchwały przez ogół właścicieli lokali, w której wyrażona została zgoda oraz udzielone pełnomocnictwo do zawierania umów stanowiących czynności przekraczające zakres zwykłego zarządu $\mathrm{w}$ formie prawem przewidzianej (art. 22 ust. 2 u.w.1.).

W tym miejscu warto jedynie wspomnieć, że uznawszy podmiotowość wspólnoty mieszkaniowej jako niepełnej osoby prawnej, ustawowe wymaganie pełnomocnictwa w art. 22 ust. 2 uznać należy za wadliwe. Niespójność konstrukcyjna tej regulacji polega na łączeniu instytucji organu niepełnej osoby prawnej ${ }^{9} \mathrm{z}$ instytucją pełnomocnika. Przepis ten wymaga bowiem, aby zarządowi wspólnoty mieszkaniowej (tj. organowi niepełnej osoby prawnej) udzielać pełnomocnictwa do dokonywania czynności przekraczających zakres zwykłego zarządu. Otwiera to drogę do licznych kontrowersji, co do których tylko częściowo wypowiedział się Sąd Najwyższy

uchwał do jednej lub drugiej grupy nie będzie identyczna. W mojej ocenie z uwagą należy odnieść się do zastrzeżeń prezentowanych w literaturze (i częściowo przeze mnie podzielanych), a dotyczących wymienionych w art. 22 ust. 3 u.w.l. uchwał, które albo nie są czynnościami zarządu, albo są podejmowane przez właścicieli lokali, a nie przez zarząd. Zob. J. Pisuliński, [w:] System Prawa Prywatnego, E. Gniewek (red.), t. 4, wyd. 2, Warszawa 2007, s. 322-323, A. Turlej, op.cit., s. 453-454.

9 Przez analogię do osób prawnych (art. $33^{1} \S 1$ k.c. w zw. z art. 38 k.c.). 
w uchwale w składzie siedmiu sędziów z 21 grudnia 2007 r. (III CZP $65 / 2007)^{10}$.

Druga $z$ wymienionych grup czynności przekraczających zakres zwykłego zarządu dotyczy takich czynności, które ingerują w prawo współwłasności nieruchomości wspólnej przysługujące każdemu właścicielowi lokalu. Przykładowo należą do nich czynności prowadzące do zmiany wysokości udziałów we współwłasności nieruchomości wspólnej (w tym czynności wymienione w art. 22 ust. 3 pkt 5, 5a, u.w.1.) ${ }^{11}$ jak i prowadzące do obciążenia nieruchomości wspólnej ograniczonym prawem rzeczowym (np. służebnością drogową). Czynności prawne dokonywane przez zarząd będą wówczas odnosiły skutek nie w sferze prawnej wspólnoty mieszkaniowej jako niepełnej osoby prawnej, lecz w sferze prawnej każdego współwłaściciela nieruchomości wspólnej. Innymi słowy, czynności te odnosić się będą do prawa własności przysługującego każdemu współwłaścicielowi. W konsekwencji zarząd będzie działał w takich sytuacjach jako pełnomocnik wszystkich współwłaścicieli, a podstawą prawną dla jego działań będzie (tak samo jak w odniesieniu do poprzedniej grupy czynności) art. 22 ust. 2 u.w.l. Istnieje zatem wymóg, aby w celu ich podjęcia zarząd działał na podstawie uchwały, w której

10 Sąd Najwyższy odniósł się w niej m.in. do poglądu bazującego na wykładni art. 22 ust. 2 u.w.1., wg którego wspólnota może nabywać prawa na podstawie czynności zwykłego zarządu, natomiast prawa nabywane na podstawie czynności przekraczających zwykły zarząd wchodzą do majątku właścicieli lokali. SN stwierdził, że taka interpretacja jest nie do pogodzenia $z$ wykładnią systemową i funkcjonalną. Wspólnota mieszkaniowa jest bowiem niepełną osobą prawną, a zarząd jest odpowiednikiem organu osoby prawnej (art. $33^{1} \S 1$ k.c.). W granicach przyznanych mu kompetencji może działać samodzielnie w odniesieniu do czynności zwykłego zarządu, natomiast co do czynności przekraczających zakres zwykłego zarządu działa na podstawie uchwały właścicieli, o której mowa w art. 22 ust. 2 u.w.1. Por. także J. Pisuliński, op.cit., s. 298-301; A. Turlej, op.cit., s. 442-444 i powołana tam literatura.

11 Pomijam tu problematyczne zagadnienia dotyczące tego uregulowania, w szczególności związane z jego relacją do art. 3 u.w.l. W tej kwestii zob. E. Bończak-Kucharczyk, op.cit., s. 397-403; J. Pisuliński, op.cit., s. 310-311; R. Dziczek, Własność lokali. Komentarz. Wzory pozwów i wniosków sądowych, wyd. 5, Warszawa 2010, s. 190 i n. 
właściciele lokali wyrazili zgodę na dokonanie takiej czynności oraz udzielili zarządowi pełnomocnictwa do zawarcia stosownej umowy. Przepis mówi o pełnomocnictwie „do zawierania umów stanowiących czynności przekraczające zakres zwykłego zarządu w formie prawem przewidzianej", nie określając, czy oświadczenie złożone na podstawie takiego pełnomocnictwa, a dotyczące prawa współwłasności nieruchomości wspólnej odniesie skutek w stosunku do właścicieli wszystkich lokali, czy też nie. Właśnie w art. 21 ust. 3 u.w.l. znajduje się specjalna regulacja, która ex lege każe uznać dla trzech przypadków w niej wymienionych, że oświadczenie złożone na podstawie pełnomocnictwa zawartego w art. 22 ust. 2 u.w.l. odniesie skutek w stosunku do właścicieli wszystkich lokali. Są to przypadki wymienione w art. 22 ust. 3 pkt 5, 5a i 6 u.w.1. ${ }^{12}$ Przyjmując wykładnię literalną, należałoby uznać, że jest to katalog zamknięty, co oznaczałoby, że do innych czynności z tej grupy (tj. do czynności, które ingerują w prawo współwłasności nieruchomości wspólnej przysługujące każdemu właścicielowi lokalu, jak np. ustanowienie służebności drogowej), oświadczenie złożone na podstawie pełnomocnictwa $z$ art. 22 ust. 2 u.w.l. nie odnosiłoby skutku w stosunku do właścicieli wszystkich lokali. Taką wykładnię przyjął Sąd Najwyższy w glosowanym orzeczeniu, uzasadniając ją jednak dość lakonicznie. W odniesieniu do tej interpretacji powstaje pytanie o sens rozwiązania, które $z$ jednej strony nakazuje udzielać pełnomocnictwa do każdej czynności przekraczającej zakres zwykłego zarządu, w tym również i tych, które należą do omawianej grupy (art. 22 ust. 2 u.w.l.), z drugiej strony uzależniając jego skuteczność wobec wszystkich właścicieli lokali od istnienia dodatkowego przepisu (takiego jak art. 21 ust. 3 u.w.1.), który de lege lata odnosi się jedynie do wąsko określonej grupy sytuacji. W przypadkach niewy-

12 Są to: a) udzielenie zgody na nadbudowę lub przebudowę nieruchomości wspólnej, na ustanowienie odrębnej własności lokalu powstałego w następstwie nadbudowy lub przebudowy i rozporządzanie tym lokalem oraz na zmianę wysokości udziałów w następstwie powstania odrębnej własności lokalu nadbudowanego lub przebudowanego (art. 22 ust. 3 pkt 5); b) udzielenie zgody na zmianę wysokości udziałów we współwłasności nieruchomości wspólnej (art. 22 ust. 3 pkt 5a); c) dokonanie podziału nieruchomości wspólnej (art. 22 ust. 3 pkt 6). 
mienionych w art. 21 ust. 3 u.w.l. pełnomocnictwu temu odmawiałoby się de facto skuteczności prawnej. Na jego podstawie pełnomocnik (zarząd) nie mógłby bowiem skutecznie działać w imieniu swoich mocodawców (właścicieli lokalu) pomimo skutecznego powzięcia uchwały, gdyż rodzaj czynności prawnej, jakiej miałby dokonać (tj. w przypadku omawianego stanu faktycznego złożyć oświadczenie woli o ustanowieniu służebności drogi koniecznej), powodowałby, że jego oświadczenie nie odnosiłoby skutku wobec wszystkich właścicieli lokali, co przeczy istocie takiego oświadczenia, niepodzielnie wpływającego na prawo współwłasności wszystkich właścicieli lokali.

W związku z powyższym uważam, przeciwnie do Sądu Najwyższego, iż de lege lata właściwą wykładnią omawianej normy prawnej jest wykładnia systemowa oraz funkcjonalna, która zakłada spojrzenie na skuteczność pełnomocnictwa przez pryzmat wszystkich przepisów o zarządzie nieruchomością wspólną, w tym w szczególności art. 23 u.w.l., który traktuje o sposobie podejmowania uchwał przez właścicieli lokali. Ustawodawca przewidział, że przy zarządzie ustawowym w tzw. dużych wspólnotach mieszkaniowych do czynności przekraczających zakres zwykłego zarządu (w tym do ustanowienia służebności drogi koniecznej) nie jest wymagana jednomyślność, lecz większość głosów właścicieli lokali liczona - co do zasady - według wielkości udziałów (art. 23 ust. 2 u.w.1.) ${ }^{13}$. Warto zaznaczyć, że ustawodawca w ogóle nie przewidział w odniesieniu do zarządu ustawowego w tzw. dużej wspólnocie mieszkaniowej jednomyślnego podejmowania uchwał ${ }^{14}$. Powzięcie zatem uchwały w trybie art. 22 ust. 2 u.w.l. wyrażającej zgodę i obligatoryjnie

13 Jednomyślność w odniesieniu do czynności przekraczających zakres zwykłego zarządu występuje w innym przypadku niż omawiany tutaj, mianowicie przy zarządzie ustawowym w tzw. małych wspólnotach mieszkaniowych. Istnieje tu bowiem odesłanie do przepisów kodeksu cywilnego (zob. art. 199 k.c.) oraz kodeksu postępowania cywilnego o współwłasności.

14 Zob. krytykę co do propozycji doktrynalnych wymogu głosowania jednomyślnego w odniesieniu do niektórych kategorii uchwał przeprowadzoną przez J. Pisulińskiego w: J. Pisuliński, op.cit., s. 309-311. Stanowisko to aprobuje także A. Turlej, op.cit., s. 445-446. Stanowisko autora oraz argumenty przedstawione w krytyce są przekonujące. 
udzielającej pełnomocnictwa powoduje, że oświadczenie woli złożone na podstawie takiego pełnomocnictwa odnosi skutek w stosunku do właścicieli wszystkich lokali, także i tych, którzy nie głosowali lub głosowali przeciwko takiej uchwale. Wynika to $\mathrm{z}$ istoty mechanizmu zarządzania nieruchomością wspólną w tzw. dużych wspólnotach mieszkaniowych, ustanowionego przez prawodawcę w u.w.l. Prawa przegłosowanego współwłaściciela chronione są przecież przez możliwość zaskarżenia uchwały do sądu z powodu naruszenia jego interesów (art. 25 u.w.1.).

W konsekwencji za zasadne należy uznać w mojej ocenie stanowisko, że do wszystkich czynności z grupy tych, które ingerują w prawo współwłasności nieruchomości wspólnej, zarówno tych wymienionych explicite w art. 21 ust. 3 u.w.1., jak i tych w niej niewymienionych (jak np. ustanowienie służebności drogowej), oświadczenie złożone na podstawie pełnomocnictwa udzielonego zgodnie $z$ art. 22 ust. 2 u.w.l. odnosi skutek w stosunku do właścicieli wszystkich lokali.

\section{SUMMARY}

\section{Gloss on the Supreme Court Judgment of 5th February 2010 (III CZP 127/09)}

This critical gloss on the Supreme Court judgment considers an effectiveness of a power of attorney issued by, so called, large housing community (dużą wspólnotę mieszkaniową) to its board. In the given judgment the Supreme Court ruled that on the basis of art. 21.3. of the Ownership of Premises Act (ustawa o własności lokali z 24.06.1994r. Dz.U. z 2000 r. $\mathrm{Nr} 80$, poz. 903, ze zm.) housing community cannot issue a power of attorney to its board for establishment of an easement of passage. Author disagrees with that and proposes functional interpretation of articles 21.3. and 22.2 of the Act. It is claimed that among actions exceeding ordinary management distinction should be made between those that just administer the co-owned estate and those which affects property rights of members of the community (like in case of establishment of an easement of 
passage). In the second group, a power of attorney granted on the basis of art. 22.2. to the members of the board enables them to make statements that affect rights of all members of the housing community, regardless of the fact that this effect is explicitly mentioned in art. 21.3. only for three kinds of actions. The reasoning is firstly, that granting power of attorney in this kind of action is obligatory on the basis of art. 22.2 of the Act and secondly, that voting procedure does not demand unanimity but only a majority consent. Therefore, an obligatory power of attorney granted on the basis of art. 22.2. of the Act affects property rights of all members of the housing community, despite of the fact that not all of them might have agreed on that. Other interpretation would made given power of attorney in other cases than those literary expressed in art. 21.3. of no practical meaning, like for example, in case of establishment of an easement of passage, which was the factual background in the commented case.

Keywords: housing community, management of a co-owned real estate, actions exceeding ordinary management, power of attorney, easement of passage 